\title{
The extent to which genetics and lean grade affect fatty acid profiles and volatile compounds in organic pork
}

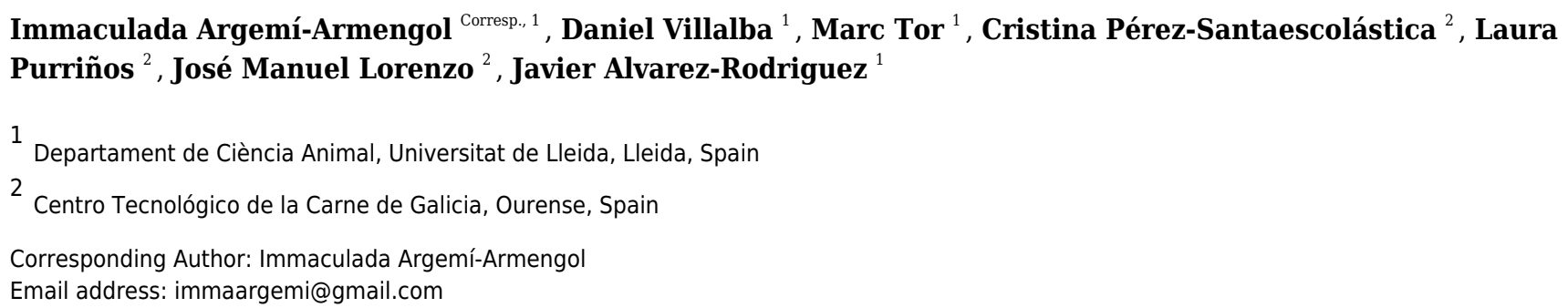

Niche production is intended to produce premium pork, but several husbandry factors may affect the meat fatty acid composition and aroma. Fatty acid profile (by GC-FID) of raw meat and volatile compounds (by SPME-GC-MS) of cooked meat were analysed in loin samples from two pig genetic types-75\% Duroc (Du) and 50\% Pietrain (Pi) rossbreds that were slaughtered at different weights (90 kg and $105 \mathrm{~kg}$, respectively) to achieve similar target carcass fatness, and the outcome carcasses were balanced for lean grade groups $(<60 \%$ or $\geq 60 \%$ lean) within genotypes. Genetic type did not affect fatty acids (FA) profile of meat. The leaner meat had lower C12:0 and C20:3n-3, lower saturated fatty acids (SFA) and higher MUFA/SFA ratio content than the fattier meat. Short-chain alcohols were lower in Pietrain and in leaner pork compared to the samples from Duroc crossbreds and fattier pork. A greater amount of hexane,2,4,4-trimethyl (an aliphatic hydrocarbon) but lower carbon disulphide (sulphur compound) content was detected in pork from leaner compared to fattier pork. Higher aromatics hydrocarbons were exclusively associated with Duroc crossbreds, and lower aliphatic hydrocarbons with pigs classified as fattier. Most of the volatile compounds detected $\mathrm{n}$ the present study came from lipid oxidation. 
1 The extent to which genetics and lean grade affect fatty acid 2 profiles and volatile compounds in organic pork

3 Immaculada Argemí-Armengol ${ }^{1}$, Daniel Villalba ${ }^{1}$, Marc Tor ${ }^{1}$, Cristina Pérez-Santaescolástica ${ }^{2}$,

4 Laura Purriños ${ }^{2}$, José Manuel Lorenzo ${ }^{2}$ and Javier Álvarez-Rodríguez ${ }^{1}$

5

$6 \quad{ }^{1}$ Departament de Ciència Animal, Universitat de Lleida, 25198 Lleida, Spain

$7 \quad{ }^{2}$ Centro Tecnológico de la Carne de Galicia, 32900 Ourense, Spain

Corresponding Author:

Immaculada Argemí-Armengol ${ }^{1}$

Avda. Rovira Roure, 191, 25198-Lleida, Spain

Email address: immaargemi@gmail.com

\section{Abstract}

Niche production is intended to produce premium pork, but several husbandry factors may affect the meat fatty acid composition and aroma. Fatty acid profile (by GC-FID) of raw meat and volatile compounds (by SPME-GC-MS) of cooked meat were analysed in loin samples from two pig genetic types-75\% Duroc (Du) and 50\% Pietrain (Pi)(crossbreds that were slaughtered at different weights ( $90 \mathrm{~kg}$ and $105 \mathrm{~kg}$, respectively) to achieve similar target carcass fatness, and the outcome carcasses were balanced for lean grade groups ( $<60 \%$ or $\geq 60 \%$ lean) within genotypes. Genetic type did not affect fatty acids (FA) profile of meat. The leaner meat had lower C12:0 and C20:3n-3, lower saturated fatty acids (SFA) and higher MUFA/SFA ratio content than the fattier meat. Short-chain alcohols were lower in Pietrain and in leaner pork compared to the samples from Duroc crossbreds and fattier pork. A greater amount of hexane,2,4,4-trimethyl (an aliphatic hydrocarbon) but lower carbon disulphide (sulphur compound) content was detected in pork from leaner compared to fattier pork. Higher aromatics hydrocarbons were exclusively associated with Duroc crossbreds, and lower aliphatic hydrocarbons with pigs classified as fattier. Most of the volatile compounds detected in the present study came from lipid oxidation.

\section{Introduction}

The flavor of cooked meat is one of the most important sensory attributes for consumers to judge the quality and it is influenced by volatile compounds (VC), formed during cooking, contributing to the sense of taste that determine the meat aroma attributes (Calkins \& Hodgen, 2007; Zhao et al., 2017).

The amount and nature of aroma precursors present in pork depends on several factors including feed, ageing, gender, post-mortem treatment and genetic variations (Meinert et al., 2007). Crossbreeding with Duroc breed as sire line allows improving meat quality traits (Ramírez and Cava, 2007). Likewise, Duroc breed is used to produce dry-cured pork products, since accumulates greater intramuscular fat and fat quality traits than other sire breeds as Pietrain, which is normally 
40

41

42

43

44

45

46

47

48

49

50

51

52

53

54

55

56

57

58

59

60

61

62

63

64

65

66

67

68

69

70

71

72

73

74

75

76

77

78

very lean (Affentranger et al. 1996; Latorre et al. 2009b). Moreover, the amount of intramuscular fat in organic pork has been reported to be higher (Sundrum et al., 2000), and the fatty acid composition to be more unsaturated (Hansen et al., 2006).

This experiment had the hypothesis that different pig genotypes, under organic husbandry, react differently to same feeding, thereby showing different fatty acid profiles in Duroc than Pietrain crossbred pork. Moreover, the arisen volatile compounds contents of this cooked pork may also be affected.

Therefore, the objective of the present study was to evaluate the potential role of genetic type and lean grade on fatty acid composition and volatile compounds of pork under organic husbandry.

\section{Materials \& Methods}

\section{Animal management and meat sampling}

A total of 48 pigs raised by 12 sows from two genetic types were used in this study. Twenty-six animals were Pietrain x (Landrace x Large White) (Pi x (LD x LW)) and 22 animals were Duroc $\mathrm{x}$ (Gascon x Duroc) (Du x (Gc x Du)). Half of the animals were females; the other half were castrates. The Pi genetic types derived from Pi line of Selección Batallé (Riudarenes, Girona, Spain) and the Du genetic types derived from Du line of German Genetic (Stuttgart-Plieningen, Germany). Pigs from both genotypes were housed together in three concrete floor pens with a space allowance $\geq 2.3 \mathrm{~m}^{2} / \mathrm{pig}$. The individual body-weight (BW) was determined at the start of the growing phase (initial age $68 \pm 15$ days) and the BW at slaughter was set at approximately $105 \mathrm{~kg}$ (Pi) or $90 \mathrm{~kg}(\mathrm{Du})$ to reach a similar carcass fatness (lean content) between genetic types (around $60 \%$ lean). Pigs were kept in accordance with the European Community standards for organic livestock and livestock products (EC-regulation 889/2008 supplementing the EC-regulation 834/2007). All pigs had the same feed ad libitum, whose ingredients were barley grain (34.8\%), maize grain $(20.0 \%)$, wheat grain $(13.4 \%)$, expeller soybean meal $(12.3 \%)$, pea $(10.0 \%)$, maize germ meal $(4.0 \%)$, vegetable protein concentrate $(2.0 \%)$, soybean oil $(0.5 \%)$, minerals $(2.6 \%)$ and vitamin-micromineral premix $(0.4 \%)$. The feed had $140 \mathrm{~g}$ of crude protein and $37 \mathrm{~g}$ of crude fat per $\mathrm{kg}$, with an analyzed fatty acid composition of $20.96 \mathrm{~g} \mathrm{SFA} / 100 \mathrm{~g}$ of identified FA, $19.98 \mathrm{~g}$ MUFA/100 g FA, 53.24 g PUFA n-6/100 g FA and 5.93 g PUFA n-3/100 g FA, and a calculated metabolizable energy content was $12.7 \mathrm{MJ} / \mathrm{kg}$ of feed. Pigs were stunned by $\mathrm{CO}_{2}$ (concentration 87\%) before slaughtering (Escorxador Frigorífic d'Avinyó S.A., Catalonia, Spain) using a dip lift system, exsanguinated, scalded, skinned, eviscerated according to standard commercial procedures and split down the midline. Hot carcass weight was individually recorded before the carcasses were refrigerated in line processing at $2^{\circ} \mathrm{C}$. The carcasses were graded with an automated image analysis system (VCS 2000, E+V Technology GmbH, Oranienburg, Germany; DOUE, $2018)$ and classified in two classes $(<60 \%, n=10$ and $>60 \%$ lean, $n=14)$. Backfat thickness was measured at 3rd-4th last thoracic rib. At $45 \mathrm{~min}$ post-mortem, the loins were excised from the carcass following the standard procedures of the abattoir and they were trimmed by an expert staff to eliminate part of the external fat for commercial requirements. Immediately afterwards, 
80

81

82

83

84

85

86

87

88

89

90

91

92

93

94

95

96

97

98

99

100

101

102

103

104

105

106

107

108

109

110

111

112

113

114

115

116

117

118

individual 10-cm caudal Longissimus lumborum was sampled (approximately $500 \mathrm{~g}$ ), packaged in polyethylene bags and stored at $4^{\circ} \mathrm{C}$ in darkness overnight.

\section{Sample selection and preparation}

One-day post-mortem, 24 L. lumborum pork samples were selected and two slices ( $1 \mathrm{~cm}$ thickness, $\sim 100 \mathrm{~g}$ each) were vacuum-packaged in plastic bags. The first slice was used to determinate total intramuscular fat content (IMF) and fatty acid composition of raw pork, thus it was stored at $20^{\circ} \mathrm{C}$, freeze-dried and minced until analysis. The second slice was used to determinate volatile compounds of cooked pork aged 8 days. Thereby, loin slice was aged in dark at $4{ }^{\circ} \mathrm{C}$ for one week and kept at $-20^{\circ} \mathrm{C}$. Before cooking, these aged loin samples were thawed at $4{ }^{\circ} \mathrm{C}$ during $24 \mathrm{~h}$, and subsequently cooked by placing the vacuum bags in a water bath $\left(95^{\circ} \mathrm{C}\right)$ with automatic temperature control to internal temperature of $70^{\circ} \mathrm{C}$, controlled by thermocouples connected to a data logger. After cooking, samples were cooled at room temperature overnight, vacuum-packaged and stored at $-20^{\circ} \mathrm{C}$ for no longer than four weeks until analysis.

\section{Fat and fatty acids (FA) content of meat}

Loin slices were trimmed of intermuscular and subcutaneous fat prior to IMF analysis. Fat content was quantified using the Ankom procedure AOCS (2005) (Official Procedure Am 5-04) with an Ankom extractor (XT10, Ankom Technology, Madrid, Spain). Analyses were run in duplicate. Meat fatty acid (FA) methyl esters were directly obtained by transesterification using a solution of methanol/sulphuric acid $2 \%(\mathrm{v} / \mathrm{v}), 30 \mathrm{~min}$ heating at $80{ }^{\circ} \mathrm{C}$, centrifugation at $3,000 \mathrm{rpm}$ during 5 min and collection of the final supernatant. Analysis of FA methyl esters were performed in duplicate by GC with a $30 \mathrm{~m} \times 0.25 \mathrm{~mm}$ capillary column (Agilent DB-23, Agilent Technologies, Santa Clara, United States) and a flame ionization detector with helium as the carrier gas at 2 $\mathrm{mL} / \mathrm{min}$. The oven temperature program increased from $150^{\circ} \mathrm{C}$ at the first min, to $180^{\circ} \mathrm{C}$ at $35^{\circ} \mathrm{C}$ per min, and to $220^{\circ} \mathrm{C}$ at $5{ }^{\circ} \mathrm{C}$ per min. The injector and detector temperatures were both $250{ }^{\circ} \mathrm{C}$. Fatty acid composition was calculated as the relative percentage of each individual FA relative to total FA. Individual FA were identified by comparing their retention times with those from a known standard Supelco ${ }^{\circledR} 37$ Component FAME Mix (Supelco, Bellefonte, PA, USA). The proportion of polyunsaturated (PUFA) (C18:2n-6; C18:3n-3; C18:3n-6; C20:2n-6; C20:3n-6; C20:3n-3 and C20:4n-6), monounsaturated (MUFA) (C16:1n-7; C17:1n-7; C18:1n-9; C18:1n-7c; C20:1n-9) and saturated (SFA) (C10:0; C12:0; C14:0; C16:0; C17:0; C18:0; and C20:0) FA contents were calculated.

\section{Volatile compounds analysis (VC)}

The extraction of the volatile compounds was performed using solid-phase microextraction (SPME) from the previously homogenized samples described in section 'sample selection and preparation' (pork aged 8 days). An SPME device (Supelco, Bellefonte, PA, USA) containing a fused-silica fibre $(10 \mathrm{~mm}$ length) coated with a $50 / 30 \mathrm{~mm}$ thickness of DVB/CAR/PDMS (divinylbenzene/carboxen/polydimethysiloxane) was used and analysis was performed as 
119 following. For headspace SPME (HS-SPME) extraction, $1 \mathrm{~g}$ of each sample was weighed in a $12020 \mathrm{~mL}$ glass vial, after being ground using a commercial grinder. The vials were subsequently 121 screw-capped with a laminated Teflon-rubber disc. The fibre was previously conditioned by 122 heating in a Fiber Conditioning Station at $270{ }^{\circ} \mathrm{C}$ for $30 \mathrm{~min}$. The conditioning, extraction and

123

124

125

126

127

128

129

130

131

132

133

134

135

136

137

138

139

140

141

142

143

144

145

146

147

148

149

150

151

152

153

154

155

156

157

injection of the samples was carried out with an autosampler PAL-RTC 120. The extractions were carried out at $37{ }^{\circ} \mathrm{C}$ for $30 \mathrm{~min}$, after equilibration of the samples for $15 \mathrm{~min}$ at the temperature used for extraction, ensuring homogeneous temperature for sample and headspace. Once sampling was finished, the fibre was transferred to the injection port the gas chromatograph-mass spectrometer (GC-MS) system.

A gas chromatograph 7890B (Agilent Technologies) was used with a DB-624 capillary column ( $30 \mathrm{~m}, 0.25 \mathrm{~mm}$ i.d., $1.4 \mu \mathrm{m}$ film thickness; J\&W Scientific, Folsom, CA, USA) coupled to a 5977B single quadrupole mass selective detector (Agilent Technologies, Palo Alto, USA). The SPME fibre was desorbed and maintained in the injection port at $260^{\circ} \mathrm{C}$ during $8 \mathrm{~min}$. The sample was injected in split less mode. Helium was used as carrier gas with a flow of $1.2 \mathrm{~mL} / \mathrm{min}(9.59$ psi). The temperature program was isothermal for $10 \mathrm{~min}$ at $40{ }^{\circ} \mathrm{C}$, raised to $200{ }^{\circ} \mathrm{C}$ at $5{ }^{\circ} \mathrm{C} / \mathrm{min}$, and then raised to $250^{\circ} \mathrm{C}$ at $20^{\circ} \mathrm{C} / \mathrm{min}$, and held for $5 \mathrm{~min}$ : total run time $49.5 \mathrm{~min}$. Injector and detector temperatures were both set at $260^{\circ} \mathrm{C}$.

The mass spectra were obtained using a mass selective detector working in electronic impact at 70 $\mathrm{eV}$, with a multiplier voltage of $850 \mathrm{~V}$ and collecting data at $6.34 \mathrm{scans} / \mathrm{s}$ over the range $\mathrm{m} / \mathrm{z} 40-$ 550. Compounds were identified by comparing their mass spectra with those contained in the NIST14 (National Institute of Standards and Technology, Gaithersburg) library, and/or by comparing their mass spectra and retention time with authentic standards (Supelco, Bellefonte, PA, USA), and/or by calculation of retention index relative to a series of standard alkanes (C5C14) (for calculating Linear Retention Index, Supelco 44585-U, Bellefonte, PA, USA) and matching them data reported in literature. The results are expressed as quantifier area units (AU) $\mathrm{x} 10^{4} / \mathrm{g}$ of sample.

Among the volatile compounds (VC) at the end of final stage, only compounds regarded as mainly representative for their presence and abundance to aroma have been take into account according to previous studies (Gorbatov 1980; Flores et al. 1997; Machiels et al. 2003; Domínguez et al. 2014a; Franco et al. 2014; Gravador et al. 2015; Benet et al. 2015; Zhao et al. 2017; PérezSantaescolástica et al. 2018; Flores 2018).

The VC were classified based on their origin (lipolysis, proteolysis and microbial), according to Dainty et al. (1985), Roger, Degas and Gripon (1988), Ruiz et al. (1999), Meynier et al.(1999), Carrapiso et al. (2002), Arnoldi (2003), Liu (2003), Machiels et al. (2003), Raes et al. (2003), Martín et al. (2006), Ramírez and Cava (2007), Calkins and Hodgen (2007), Narváez-Rivas et al. (2012), Fonseca et al. (2015) and Rivas, Gallardo and Camacho (2016), Pérez-Santaescolástica et al. (2019).

\section{Statistical analysis}

PeerJ reviewing PDF | (2019:04:37107:1:2:NEW 15 Jun 2019) 
158 The data were analyzed with the JMP Pro 13 statistical software (SAS Institute, Cary, NC, USA)

159

160

161

162

163

164

165

166

167

168

169

170

171

172

173

174

175

176

177

178

179

180

181

182

183

184

185

186

187

188

189

190

191

192

193

194

195

196

with a least square mean standard model including genetic type, lean grade and sex as fixed effects.. Differences $(\mathrm{P} \leq 0.05)$ between least square means were assessed with the Tukey test. Tendencies were reported when the P-value ranged between 0.05 and 0.10. A Spearman's rank correlation analysis between FA and VC content was performed.

Classification trees (partition option from multivariate methods) from JMP Pro software were used to predict both genetic type and carcass grading as a function of potential predictor variables (19 fatty acids and 69 volatiles compounds) using recursive partitioning. The partition algorithm searched all possible splits of predictors to best predict the response (FA or VC). These splits (or partitions) of the data were done recursively to form a tree of decision rules. The variables were selected according to G2 (likelihood-ratio chi-square) test of association and $\log w o r t h(-\log (\mathrm{p}-$ value)) value. The logworth values are the logs of adjusted $p$-values for the chi-square test of independence. These are adjusted to account for the number of ways that splits can occur. The partition algorithm imputes -that is, randomly assigns- values for the missing values, and this allows the variables that are poorly populated to be noticed, if they indeed help explain banding. If the logworth is greater than 2, the variable that is used in the branch is considered significant and should be included in the tree.

\section{Results}

\section{Fatty acids composition of raw pork}

The results concerning IMF and FA composition of raw pork (24 h post-mortem) according to genetic type and lean content is detailed in Table 1. Total IMF was not significantly affected by genetic type and lean grade $(\mathrm{P}>0.05)$. Nineteen FA were detected and quantified, which the percentage of oleic acid (C18:1n-9) was the highest, ranging from $36.5 \%$ to $38.8 \%$, followed by palmitic acid (C16:0) from $21.9 \%$ to $23 \%$ and linoleic acid (C18:2n-6) from $15.1 \%$ to $16.4 \%$. No significant differences were observed in FA contents between genetic types $(\mathrm{P}>0.05)$. However, Du pigs tended to show higher SFA content than Pi pigs $(\mathrm{P}=0.10)$, due to a tendency for higher proportions of palmitic acid (C16:0) and myristic acid (C14:0) $(\mathrm{P}=0.08)$. Likewise, Du pigs tended to show higher dihomo- $\gamma$-linolenic acid $(\mathrm{C} 20: 3 n-6)$ than Pi-sired pigs $(\mathrm{P}=0.10)$.

On the contrary, individual FA differed between lean grades, especially the SFA lauric acid (C12:0) and the omega-3 PUFA eicosatrienoic acid (C20:3n-3), with leaner carcasses ( $\geq 60 \%$ lean) showing greater lauric acid content $(\mathrm{P}=0.05)$ and lower eicosatrienoic acid content $(\mathrm{P}=0.05)$ than fatter carcasses $(<60 \%$ lean). The leaner carcasses tended to show higher total SFA content than fatter carcasses $(P=0.10)$. Accordingly, the MUFA/SFA ratio of leaner carcasses $(\geq 60 \%$ lean) was lower $(\mathrm{P}=0.05)$ than in fatter carcasses $(<60 \%$ lean $)$. However, the PUFA/SFA ratio in raw pork was not affected by lean content $(\mathrm{P}>0.10)$. There were significant differences $(\mathrm{P}<0.05)$ between genders in the margaric acid (C17:0), oleic acid (C18:1n-9), cis-gadoleic acid (C20:1n-9) and MUFA/SFA ratio. Pork from females had more margaric acid $(\mathrm{C} 17: 0)$ than males $(\mathrm{P}<0.05)$. However, the MUFA oleic acid (C18:1n-9) and cis-gadoleic acid (C20:1n-9) were higher in pork

PeerJ reviewing PDF | (2019:04:37107:1:2:NEW 15 Jun 2019) 
197 from males than in that of females $(\mathrm{P}<0.05)$. Accordingly, the MUFA/SFA ratio was higher in

198

199

200

201

202

203

204

205

206

207

208

209

210

211

212

213

214

215

216

217

218

219

220

221

222

223

224

225

226

227

228

229

230

231

232

233

234

235

236

pork from males than in that of females $(\mathrm{P}<0.05)$.

\section{Volatile compounds of cooked aged pork}

A total of $69 \mathrm{VCs}$ were determined and they were assigned to the following chemical families: 18 hydrocarbons, 13 aldehydes, 8 ketones, 7 carboxylic acids, 15 alcohols, 3 esters and ethers, 2 sulphur-containing and 3 furans. Alcohols and aldehydes accounted for the highest percentage (42.1\% and 22.7\%, respectively, as shown in Figure 1a). The chemical families of VC were not affected by genetic type and lean grade $(\mathrm{P}>0.10)$. However, Du pork tended to show higher aromatic and cyclic hydrocarbons content than Pi pork $(\mathrm{P}=0.10)$. Fifty-nine out of the 69 identified VC were classified based on their origin (lipolysis, proteolysis and microbial), and 10 had an unknown origin. Lipolysis origin showed the highest level (72.4\% out of total VC) (Figure $1 b)$, followed by proteolysis and microbial activity. The origin group of VC were not significantly influenced by the genetic type or lean grade $(\mathrm{P}>0.10)$. Meanwhile, pork classed as leaner had higher content of VC from unknown origin $(\mathrm{P}<0.01)$.

The average contents of extracted VC of cooked aged pork are shown in Tables 2, 3 and 4. Through GC-MS analysis, there were several peaks in chromatogram that were not included in the list of VC, because most of them were tentatively identified as siloxanes or silanes and the most probable origin will be the trap (fiber). Concerning the effect of genetic type, there were only significant differences in the alcohol 1-pentanol content, which was greater in pork from Du than in pork from Pi pigs $(\mathrm{P}<0.05)$. Likewise, lean grade affected the content of hydrocarbon hexane, 2,4,4trimethyl in cooked aged pork, being greater in pigs classed as leaner ( $\geq 60 \%$ lean) than fattier pigs $(<60 \%$ lean) $(\mathrm{P}<0.05)$. Nevertheless, fattier pigs $(<60 \%$ lean $)$ had higher content of certain alcohols such as 1 -butanol $(\mathrm{P}<0.05)$ and 1 -pentanol $(\mathrm{P}<0.05)$ than leaner pigs $(\geq 60 \%$ lean $)$. The only significant differences between genders in VC were on the alcohols 1-butanol and phenylethyl, that were higher in pork from gilts than in that from barrows (6.7 vs. $2.9 \pm 0.97$ and 13.4 vs. $2.0 \pm 3.2 \mathrm{AU} \mathrm{x} 10^{4} / \mathrm{g}$ of cooked pork, $\mathrm{P}<0.05$, respectively).

\section{Correlations between Volatile compounds and Fatty acids}

Concerning hydrocarbons, the concentration of undecane (1-Undecene, 9-methyl-) was positively correlated $(0.41 \leq \mathrm{r} \leq 0.53 ; \mathrm{P}<0.05)$ with percentages of margaric acid $(\mathrm{C} 17: 0)$, heptadecenoic acid (C17:1n-7), linoleic acid (C18:2n-6), alfa-linolenic acid (C18:3n-3), total PUFA, and also, PUFA/SFA ratio. However, the concentration of undecane was negatively correlated $(-0.43 \leq \mathrm{r} \leq$ -0.47; $\mathrm{P}<0.05)$ with oleic acid (C18:1n-9) and cis-gadoleic acid (C20:1n-9). The concentration of 2,4,4-trimethyl- hexane showed a negative correlation $(-0.56 \leq \mathrm{r} \leq-0.57 ; \mathrm{P}<0.01)$ with lauric acid (C12:0) and myristic acid (C14:0).

A positive correlation between the concentration of aldehyde 2-octanal,(E)- and myristic acid content $(\mathrm{C} 14: 0)(\mathrm{r}=0.49, \mathrm{P}<0.05$, as well as between 2-octanal,(E)- and total SFA $(\mathrm{r}=0.55 ; \mathrm{P}<$ $0.01)$ was found. In contrast, the concentration of propanal, pentanal and hexanal aldehydes

Peer] reviewing PDF | (2019:04:37107:1:2:NEW 15 Jun 2019) 
237 showed negative correlations $(-0.40 \leq \mathrm{r} \leq-0.47 ; \mathrm{P}<0.05)$ with contents of lauric acid $(\mathrm{C} 12: 0)$, 238 myristic acid (C14:0) and arachidic acid (C20:0).

239 The concentration of 3-hydroxy-3-methyl-2-butanone (ketone) exhibited strong positive 240 correlations $(\mathrm{r}=0.70 ; \mathrm{P}<0.001)$ with contents of individual PUFA dihomo- $\gamma$-linolenic acid 241 (C20:3n-6) and arachidonic acid (C20:4n-6). The concentration of both acetoin (ketone) and acetic 242 acid ethenyl ester (ester) showed positive correlations $(0.62 \leq \mathrm{r} \leq 0.65$; $\mathrm{P}<0.001)$ with MUFA 243 palmitoleic acid (C16:1n-7) content. On the contrary, the concentration of ethyl acetate, acetic acid 244 ethenyl ester and acetoin showed negative correlations $(-0.42 \leq \mathrm{r} \leq-0.49 ; \mathrm{P}<0.05)$ with linoleic 245 acid (C18:2n-6), gamma-linolenic acid (C18:3n-6), alfa-linolenic acid (C18:3n-3), total PUFA, 246 and PUFA/SFA ratio.

247 The concentration of butanoic acid (carboxylic acid compound), 3-methyl- showed positive 248 correlations $(\mathrm{r}=0.55 ; \mathrm{P}<0.01)$ with the percentage of $\mathrm{C} 14: 0$ and $\mathrm{C} 16: 0$. However, the 249 concentration of pentanoic acid had negative correlation with the content of $\mathrm{C} 14: 0(\mathrm{r}=-0.43 ; \mathrm{P}<$ $2500.05)$ but the former has a positive correlation with $\mathrm{C} 18: 3 n-3(\mathrm{r}=0.41, \mathrm{P}<0.05)$.

251 Regarding alcohols, the concentration of 1-Butanol, 3-methyl-, 2,3-Butanediol -[S-(R*, $\left.\left.\mathrm{R}^{*}\right)\right]-$ and 252 1-octen-3-ol showed a positive correlation $(0.42 \leq \mathrm{r} \leq 0.48 ; \mathrm{P}<0.05)$ with the content of 253 arachidonic acid (C20:4n-6) and dihomo- $\gamma$-linolenic acid (C20:3n-6). On the contrary, the 254 concentration of 1-heptanol showed a negative correlation with the percentage of C20:4n-6 ( $\mathrm{r}=$ $2550.57 ; \mathrm{P}<0.01)$.

256 The concentration of carbon disulphide (sulfur compound), only showed a negative correlation 257

258

259

260

261

262

263

264

265 with the content of lauric acid (C12:0) $(\mathrm{r}=-0.45 ; \mathrm{P}<0.05)$. In contrast, the concentration of furans, 2-ethyl-, 2-n-butyl, and 2-pentyl-, showed a positive correlation $(0.44 \leq \mathrm{r} \leq 0.46 ; \mathrm{P}<0.05)$ with content of individual PUFA arachidonic acid (C20:4n-6).

\section{Partition trees}

The best partition tree of FA based on genetic type resulted in two splits (Figure 2a). The final coefficient of determination $\left(\mathrm{R}^{2}\right.$ square) for the validation set was 0.52 . The column contributions report (based on G2) showed that PUFA/SFA ratio of raw meat and myristic acid (C14:0) are the main predictors of genetic type in the partition tree model. The lower PUFA/SFA ratio $(<0.48)$

266

267 was exclusively associated with Du crossbred pork (100\%). Within the cooked aged pork showing 268 higher PUFA/SFA ratio ( $\geq 0.48)$, more Pi crossbred pork $(85.7 \%)$ showed lower C14:0 content 269 $(<1.4 \%)$, whereas Du crossbred pork $(71.4 \%)$ had higher C14:0 $(\geq 1.4 \%)$. Another partition tree (Figure 2b) was developed to identify VC profile of organic cooked pork based on genetic type. 270

271 The final RSquare for the validation set was 0.58. The column contributions report (based on G2) 272 the main predictors of genetic type in the partition tree model. We found that higher cyclopropane, showed that cyclopropane, pentyl- (cyclic hydrocarbon) and methanethiol (sulphur compound) are 273 pentyl- content ( $\geq 12 \mathrm{AU} \mathrm{x10} / \mathrm{g}$ ) was exclusively associated at Du crossbred (100\%). Within the

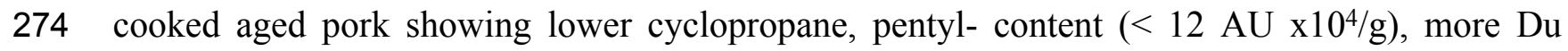
275 crossbred pork (66.7\%) showed lower methanethiol $(<0.8$ AU x10 $/ \mathrm{g})$, whereas higher 276 methanethiol ( $\geq 0.8 \mathrm{AU} \times 10^{4} / \mathrm{g}$ ) was exclusively associated with Pi crossbred pork $(100 \%)$. 
277 The third partition tree of FA, based on lean content, showed two splits, and the proportion of 278 observations in each split is shown in Figure 3a. The final coefficient of determination for the 279 validation set was 0.51 . Thus, the column contributions report (based on G2) showed that total 280 SFA content of pork and margaric acid (C17:0) are the main predictors in the partition tree model. 281 The higher SFA content $(\geq 37.6 \%)$ was exclusively associated with pigs with higher level of 282 fatness $(<60 \%$ lean; 100\%). Within the cooked aged pork having the lower SFA content $283(<37.5 \%)$, more fattier pigs $(71.4 \%)$ showed lower $\mathrm{C} 17: 0$ content $(<0.31 \%)$, whereas leaner pigs 284 (88.9\%) had higher $\mathrm{C} 17: 0(\geq 0.31 \%)$. A fourth partition tree was developed to identify VC profile 285 of organic cooked pork based on lean content (Figure 3b). The final RSquare for the validation set

286

287

288

289

290

291

292

293

294

295

296

297

298

299

300

301

302

303

304

305

306

307

308

309

310

311

312

313

314

315

316

was 0.64 . The column contributions report (based on G2) showed that hexane, 2,4,4-trimethyl and carbon disulphide were the main predictors in the partition tree model. Higher hexane, 2,4,4-

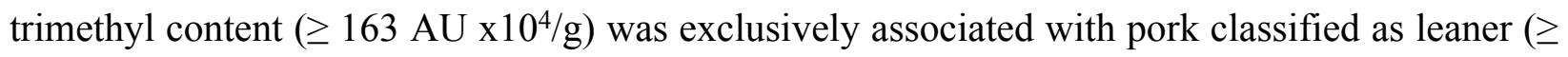
$60 \%$ lean; $100 \%$ ). Within the cooked aged pork having lower hexane, 2,4,4-trimethyl content (< $163 \mathrm{AU} \mathrm{x10} / \mathrm{g}$ ), carbon disulphide content was higher $\left(\geq 8 \mathrm{AU} \times 10^{4} / \mathrm{g}\right)$ in pork classified as fattier ( $<60 \%$ lean; $100 \%$ ). More pigs classified as leaner $(57.1 \%)$ showed lower carbon disulphide

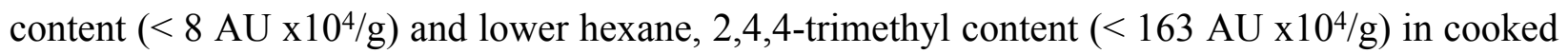
aged pork loin.

\section{Discussion}

\section{Fatty acids composition of raw pork}

This study analyzed the relevance of genetic type and lean grade on fatty acid profiles and volatile compounds in pork under organic husbandry. These effects were assessed both independently and together (by testing its interaction). MUFA were the most prevailing group in the two pork genotypes studied (highest value for oleic acid, C18:1n-9), followed by SFA and PUFA. In the present study, $75 \%$-Du crossbreds showed higher percentages of SFA in loin compared to their $50 \%$-Pi counterparts, which had greater MUFA/SFA ratio. However, the results indicated that the individual intramuscular FA did not differ between genetic types (Du vs. Pi), possibly due to targeted lack of differences in carcass and meat fatness as well as similar age between them (Argemí-Armengol et al., 2019). Previous research demonstrates minimal differences in fatty acid composition among similar genetic types to those used in the current study. Our results agreed with Cameron et al. (1990) and Latorre et al. (2009b), who found only higher myristic acid (C14:0) concentrations in Du than in Pi genetics.

On the contrary, the leaner carcasses $(>60 \%$ lean) had lower acid lauric $(\mathrm{C} 12: 0)$ and eicosatrienoic acid (C20:3n-3) but greater MUFA/SFA ratio content than the fattier meat $(<60 \%)$.

While most SFA and MUFA can be efficiently synthesized in vivo, the lack of differences in PUFAs C18:2n-6 and C18:3n-3 proportions, which may be attributed to dietary factors (Calkins and Hodgen, 2007; Juárez et al., 2017), proves that both genetic types adapted similarly to the feed composition supply. Indeed, the SFA content of meat is positively correlated with carcass fatness (Fiego et al., 2005; Latorre et al., 2009a), which contributes to decrease the MUFA/SFA ratio and reduces the nutritional quality of pork (Scollan et al., 2017). Nevertheless, the lean content hardly

Peer] reviewing PDF | (2019:04:37107:1:2:NEW 15 Jun 2019) 
317 affected the fatty acid groups either, probably because the lowest lean class was not excessively 318 fatty, and due to their similar levels of intramuscular fat. In turn, the lower eicosatrienoic acid 319 (C20:3n-3) content in leaner meat might be related to a lower feed intake pattern in lean compared 320 to fatty pigs, which couples with their lower growth performance (Argemí-Armengol et al., 2019), 321 and thereby this may reduce its biosynthesis from dietary C18:3n-3 (Sibbons et al., 2018).

322 Volatile compounds of cooked aged pork

323 While abundant research has been conducted regarding the $\mathrm{VC}$ derived from pork products 324 (cooked and/or cured with long ripening periods), less information is available for meat. 325 Thousands of volatile compounds are generated during thermal processing that belong to various 326 327 chemical classes: hydrocarbons, alcohols, aldehydes, ketones, carboxylic acids, esters, furans, sulfuric compounds and others (Kosowska et al, 2017), which are produced through lipid oxidation, or through Maillard reaction or Strecker degradation (Mottram, 1998) or microbial degradation and others, which are responsible for meat flavour development. In the present study, higher cyclic hydrocarbons were observed in cooked loins from $75 \%$ Du compared to $50 \%-\mathrm{Pi}$ crossbreds. More Du crossbreds were associated with greater concentrations of cyclopropane, pentyl- (an aromatic hydrocarbon), whereas more Pi crossbred pork had greater concentration of methanethiol (volatile sulphur compound from amino acid breakdown). Accordingly, methanethiol may not be a pleasant VC. Similarly, Benet et al. (2015) found greater methanethiol abundance in low than in high fat cooked cured ham. While most aliphatic hydrocarbons have not previously involved in meat aroma (Flores, 2018), methanethiol has been associated with sulfur and gasoline odor descriptors in pork broth from Chinese black-pig (Zhao et al., 2017) as well as with rotten eggs, sewage and cabbage in cured meat products (Flores, 2018). A greater amount of hexane 2,4,4-trimethyl (an aliphatic hydrocarbon) but lower carbon disulphide (sulfur compound) was detected in pork from leaner compared to fattier pork. According to Olivares et al. (2011), hexane is one of the volatile compounds come from lipid autooxidation. The sensory descriptions for hexane may be alkane and spicy (Pérez-Santaescolástica et al., 2018). Lorenzo and Domínguez (2014) reported that, compared with other cooking methods (grilled and roasted treatments), the application of heat for a short time led to a greater amount of hexane, and in general aliphatic hydrocarbons. In turn, carbon disulphide is an important intermediate of the Maillard reaction in the formation of heterocyclic compounds (Mottram and Mottram, 2002), but to our knowledge it seems uninvolved in aroma formation. Overall, even though Sánchez-Peña et al. (2005) reported that aliphatic hydrocarbons, because of their abundance, could play an important role in the aroma of dry-cured meat and play an important role in the overall flavor, their involvement in cooked loin primal may not be relevant.

\section{Correlations between Volatile compounds and Fatty acids}

The concentration of short-chain alcohols (mainly 1-pentanol and butanol) were lower in Pi and in leaner pork compared to the samples from $75 \%$ Du crossbreds and fattier pork, which may counterbalance the high values of methanethiol. In this regard, 1-pentanol is produced by the degradation of homologous aldehydes during lipid and amino acid oxidation (Garcia et al., 1991), and it has a mild odour, fruit and balsamic aroma (Calkins and Hodgen, 2007), which may favour 
357 the overall aroma from Du and/or fattier pork. Most of the linear alcohols identified are oxidative

358

359

360

361

362

363

364

365

366

367

368

369

370

371

372

373

374

375

376

377

378

379

380

381

382

383

384

385

386

387

388

389

390

391

392

393

394

395

396

decomposition products of lipids. For example, 1-butanol can come from miristoleic acid (C14:1) and 1-pentanol from linoleic acid (C18:2n-6), 1-hexanol may be formed from palmitoleic (C12:1) and oleic acid (C18:1n-9), and 1-octanol from oleic acid oxidation (Forss, 1973; Flores et al., 1997). Among the volatile compounds, the levels of 1-butanol were significantly correlated with the aromas of French dry-cured ham (Buscailhon et al., 1994). The methyl and ethyl branched alcohols are probably derived from proteolysis, that is the Strecker degradation of amino acids (Martín et al., 2006; Narváez-Rivas et al.; 2012; Fonseca et al., 2015).

Hexane 2,4,4-trimethyl was negatively associated with lauric acid (C12:0) and myristic acid (C14:0). In addition, the most representative aldehydes (pentanal and hexanal) were also negatively correlated with C14:0. Meynier et al (1998) found that hexanal was the major compound from the oxidation of $n-6$ fatty acids (mainly linoleic, C18:2n-6 and arachidonic acid, C20:4n-6) in pork loin, with odor descriptions for hexanal may be green (Zhao et al., 2017), which oxidized rapidly when heated (Wood et al., 2004).

The propanal aldehyde (with sensory attribute almond-like green and toasted) was present in all samples at same level, which was the main compound family in cooked foal meat in Domínguez et al. (2014b). Most PUFA (C18:2n-6, C18:3n-6, C18:3n-3 and C20:2n-6) were negatively correlated with acetoin (carboxylic acid) and acetic acid ethenyl ester (ester). The esters are formed from the interaction between free fatty acids and alcohols generated by lipid oxidation in the intramuscular tissue, specifically ethyl esters are formed through esterification reactions between ethanol and carboxylic acids (Peterson and Chang, 1982).

However, arachidonic acid (C20:4n-6) was positively correlated with some ketones and furans, which suggest that these compounds may be derived from the oxidation of $n-6$ fatty acids, and it would prove the susceptibility of PUFA to oxidation (Gravador et al, 2015). In this sense, Gandemer (2002) found that 2-pentylfuran in meat had sensory attributes as buttery and rancid, while Arnoldi (2003) found that it had odour notes as fruity and sweet; which it would have been generated during heating from linoleic acid (C18:2n-6) oxidation (Ruiz et al., 1999).

\section{Conclusions}

When pigs were slaughtered at similar carcass fatness, the 75\%-Du had similar FA composition of loin meat compared to 50\%-Pi genetic type, but Du genetics was prone to have low PUFA/SFA ratio $(<0.48)$. However, the fattier carcasses $(<60 \%$ lean $)$ had a higher percentage of SFA $(>37.6 \%)$ than leaner carcasses $(>60 \%$ lean).

Overall, the aromatic and cyclic hydrocarbons in Du were higher than in Pi pork, which had higher content of carbon disulphide (sulphur compound). The Du and fattier pork presented higher amount of pentanol and butanol (alcohols), whereas leaner carcasses had the higher content of hexane 2,4,4-trimetil (aliphatic hydrocarbon). Most of the volatile compounds detected in the present study came from lipid oxidation.

Present results suggest that lean content rather than genetic type affected the FA composition of pork from pigs under organic husbandry which are slaughtered at light live-weights. However, the

Peer) reviewing PDF | (2019:04:37107:1:2:NEW 15 Jun 2019) 
397 volatile compounds of cooked pork were dependent on both genetic type and lean grade. 398 Understanding the contribution of each factor and their interactions will help the pork industry in 399 the production of consistent premium products.

400 Acknowledgements

401 The authors thank the owners from 'Gestió Agroecològica Porcina' farm (Solsona, Catalonia, 402 Spain), and are indebted to 'Escorxador Frigorífic d'Avinyó' (Catalonia, Spain) for kindly 403 supplying pork samples. J.M. Lorenzo is member of the MARCARNE network, funded by 404 CYTED (ref. 116RT0503).

405

406

407

408

409

410

411

412

413

414

415

416

417

418

419

420

421

422

423

424

425

426

427

428

429

\section{References}

Affentranger P, Gerwig C, Seewer G J F, Schwörer D, Künzi N. 1996. Growth and carcass characteristics as well as meat and fat quality of three types of pigs under different feeding regimens. Livestock Production Science 45(2): 187-196.

AOCS. 2005. Approved procedure Am 5-04, Rapid determination of oil/fat utilizing high temperature solvent extraction. AOCS Press: Urbana, EEUU.Argemí-Armengol I, Villalba D., Ripoll G. and Álvarez-Rodríguez J. Summitted to Livestock Science 2019. Genetic but not lean grade impact on growth, carcass traits and pork quality under organic husbandry., under review after major revision.

Arnoldi A. 2003. The Maillard reaction as a source of off-flavours. Taints and off-flavours in food $162-175$.

Benet I, Guàrdia M D, Ibañez C, Solà J, Arnau J, Roura E. 2015. Analysis of SPME or SBSE extracted volatile compounds from cooked cured pork ham differing in intramuscular fat profiles. LWT-Food Science and Technology 60(1): 393-399.

Buscailhon S, Berdague J-L, Monin G. 1994. Time-related changes in volatile compounds of lean tissue during processing of French dry-cured ham. Journal of the Science of Food and Agriculture 63: 69-75.

Cameron N D, Warriss P D, Porter S J, Enser M B. 1990. Comparison of Duroc and British Landrace pigs for meat and eating quality. Meat Science 27: 227-247.

Calkins C R, Hodgen J M. 2007. A fresh look at meat flavor. Meat science 77(1): 63-80.

Carrapiso A I, Jurado Á, Timón M L, García C. 2002. Odor-active compounds of Iberian hams with different aroma characteristics. Journal of Agricultural and Food Chemistry 50(22): 6453-6458.

Dainty R H, Edwards R A, Hibbard C M. 1985. Time course of volatile compound formation 
430

431

432

433

434

435

436

437

438

439

440

441

442

443

444

445

446

447

448

449

450

451

452

453

454

455

456

457

458

459

460

during refrigerated storage of naturally contaminated beef in air. Journal of Applied Bacteriology 59(4): 303-309.

Domínguez R, Gómez M, Fonseca S, Lorenzo J M. 2014a. Effect of different cooking methods on lipid oxidation and formation of volatile compounds in foal meat. Meat science 97(2): 223230.

- Domínguez R, Gómez M, Fonseca S, Lorenzo J M. 2014b. Influence of thermal treatment on formation of volatile compounds, cooking loss and lipid oxidation in foal meat. LWT-Food Science and Technology, 58(2), 439-445.

DOUE 256/84. 2018. Decisión de ejecución (UE) 2018/1521 de la Comisión, de 10 de octubre de 2018 que modifica la Decisión 2009/11/CE relativa a la autorización de métodos de clasificación de las canales de cerdo en España.

Fiego D L, Santoro P, Macchioni P, De Leonibus E. 2005. Influence of genetic type, live weight at slaughter and carcass fatness on fatty acid composition of subcutaneous adipose tissue of raw ham in the heavy pig. Meat Science 69(1): 107-114.

Flores M, Grimm C C, Toldrá F, Spanier A M. 1997. Correlations of sensory and volatile compounds of Spanish "Serrano" dry-cured ham as a function of two processing times. Journal of Agricultural and Food Chemistry 45(6): 2178-2186.

Flores M. 2018. Understanding the implications of current health trends on the aroma of wet and dry cured meat products. Meat Science 144: 53-61.

Fonseca S, Gómez M, Domínguez R, Lorenzo J M. 2015. Physicochemical and sensory properties of Celta dry-ripened "salchichón” as affected by fat content. Grasas y Aceites 66(1): e59.

Forss D A. 1973. Odor and flavor compounds from lipids. Progress in the Chemistry of Fats and other Lipids 13: 177-258.

Franco D, Vazquez J A, Lorenzo J M. 2014. Growth performance, carcass and meat quality of the Celta pig crossbred with Duroc and Landrance genotypes. Meat Science 96(1):195-202.

Garcia C, Berdague J L, Antequera T, López-Bote C. 1991. Volatile components of dry cured Iberian ham. Food Chemistry 41(1): 23-32.

Gandemer G. 2002. Lipids in muscles and adipose tissues, changes during processing and sensory properties of meat products. Meat Science 62(3): 309-321.

Gorbatov V M, Lyaskovskaya Yu N. 1980. Review of the flavour-contributing volatiles and watersoluble non-volatiles in pork meat and derived products. Meat Science 4(3): 209-225. 
461

462

463

464

465

466

467

468

469

470

471

472

473

474

475

476

477

478

479

480

481

482

483

484

485

486

487

488

489

490

491

Gravador R S, Serra A, Luciano G, Pennisi P, Vasta V, Mele M, Priolo A. 2015. Volatiles in raw and cooked meat from lambs fed olive cake and linseed. Animal 9(4): 715-722.

Hansen L L, Claudi-Magnussen C, Jensen S K, Andersen H J. 2006. Effect of organic pig production systems on performance and meat quality. Meat Science 74(4): 605-615.

Juárez M, Dugan M E R, López-Campos Ó, Prieto N, Uttaro B, Gariépy C, Aalhus J L. 2017. Relative contribution of breed, slaughter weight, sex, and diet to the fatty acid composition of differentiated pork. Canadian Journal of Animal Science 97: 395-405.

Kosowska M, A Majcher A M, Fortuna T. 2017. Volatile compounds in meat and meat products. Food Science and Technology 37(1): 1-7.

Latorre M A, Ripoll G, García-Belenguer E, Ariño L. 2009a. The effect of gender and slaughter weight on loin and fat characteristics of pigs intended for Teruel dry-cured ham production. Spanish Journal of Agricultural Research 7: 407-416.

Latorre M A, Iguácel F, Sanjoaquín L, Revilla R. 2009b. Effect of sire breed on carcass characteristics and meat and fat quality of heavy pigs reared outdoor and intended for drycured meat production. Animal 3(3): 461-467.

Liu S Q. 2003. Practical implications of lactate and pyruvate metabolism by lactic acid bacteria in food and beverage fermentations. International Journal of Food Microbiology 83(2): 115131.

Lorenzo J M, Domínguez R. 2014. Cooking losses, lipid oxidation and formation of volatile compounds in foal meat as affected by cooking procedure. Flavour and fragrance journal 29(4): 240-248.

Martín A, Córdoba J J, Aranda E, Córdoba M G, Asensio M A. 2006. Contribution of a selected fungal population to the volatile compounds on dry-cured ham. International Journal of Food Microbiology 110(1): 8-18.

Machiels D, Van Ruth S M, Posthumus, M A, Istasse L. 2003. Gas chromatography-olfactometry analysis of the volatile compounds of two commercial Irish beef meats. Talanta 60(4): 755764.

Meinert L, Andersen L T, Bredie W L, Bjergegaard C, Aaslyng M D. 2007. Chemical and sensory characterisation of pan-fried pork flavour: Interactions between raw meat quality, ageing and frying temperature. Meat science 75(2): 229-242.

Meynier A, Genot C, Gandemer G. 1998. Volatile compounds of oxidized pork phospholipids. 
492

493

494

495

496

497

498

499

500

501

502

503

504

505

506

507

508

509

510

511

512

513

514

515

516

517

518

519

520

521

522

Journal of the American Oil Chemists' Society 75(1): 1-7.

Meynier A, Novelli E, Chizzolini R, Zanardi E, Gandemer G, 1999. Volatile compounds of commercial Milano salami. Meat Science 51(2): 175-183.

Mottram D S. 1998. Flavour formation in meat and meat products: a review. Food chemistry 62(4): 415-424.

Mottram D S, Mottram H R. 2002. An overview of the contribution of sulphur-containing compounds to the aroma in heated foods. In Heteroatomic aroma compounds. GA Reineccius and TA Reineccius. American Chemical Society 73-92., Washington, DC, USA.

Narváez-Rivas M, Gallardo E, León-Camacho M. 2012. Analysis of volatile compounds from Iberian hams: a review. Grasas y Aceites 63(4):432-454.

Olivares A, Navarro J L, Flores M. 2011. Effect of fat content on aroma generation during processing of dry fermented sausages. Meat Science 87(3): 264-273.

Pérez-Santaescolástica C, Carballo J, Fulladosa E, Garcia-Perez J V, Benedito J, Lorenzo J M. 2018. Effect of proteolysis index level on instrumental adhesiveness, free amino acids content and volatile compounds profile of dry-cured ham. Food Research International 107: 559566.

Pérez-Santaescolástica C, Carballo J, Fulladosa E, Munekata P E S, Campagnol P B, Gómez B, Lorenzo J M. 2019. Influence of high-pressure processing at different temperatures on free amino acid and volatile compound profiles of dry-cured ham. Food Research International 116: 49-56.

Peterson R J, Chang S S. 1982. Identification of volatile flavor compounds of fresh frozen beef stew and a comparison of these with those of canned beef stew. Journal of Food Science, 47: 1444-1448

Raes K, Balcaen A, Dirinck P, De Winne A, Claeys E, Demeyer D, De Smet S. 2003. Meat quality, fatty acid composition and flavour analysis in Belgian retail beef. Meat science 65(4): 12371246.

Ramírez R, Cava R. 2007. Volatile profiles of dry-cured meat products from three different Iberian X Duroc genotypes. Journal of agricultural and food chemistry 55(5): 1923-1931.

Rivas M N, Gallardo E, Camacho M L. 2016. Study of volatile alcohols and esters from the subcutaneous fat during ripening of Iberian dry-cured ham. A tool for predicting the drycuring time. Grasas y aceites 67(4): 10. 
523 Roger S, Degas C, Gripon J C. 1988. Production of phenyl ethyl alcohol and its esters during 524 ripening of traditional Camembert. Food chemistry 28(2): 129-140.

525 Ruiz J, Ventanas J, Cava R, Andrés A, García C. 1999. Volatile compounds of dry-cured Iberian 526 ham as affected by the length of the curing process. Meat Science 52(1): 19-27.

527 Solomon M B. 2004. Effect of animal production on meat quality. In Quality of Fresh and 528 Processed Foods. Springer, Boston, MA: 1-23.

529 Sánchez-Peña C M, Luna G, García-González D L, Aparicio R. 2005. Characterization of French 530 and Spanish dry-cured hams: Influence of the volatiles from the muscles and the subcutaneous 531 fat quantified by SPME-GC. Meat Science 69: 635-645.

532 Scollan N, Price E, Morgan S, Huws S, Shingfield K. 2017. Can we improve the nutritional quality

533

534

535

536

537

538

539

540

541

542

543

544

545 of meat? Proceedings of the Nutrition Society 76(4): 603-618.

Sibbons C M, Irvine N A, Pérez-Mojica J E, Calder P C, Lillycrop K A, Fielding B A and Burdge G C. 2018. Polyunsaturated Fatty Acid Biosynthesis Involving $\Delta 8$ Desaturation and Differential DNA Methylation of FADS2 Regulates Proliferation of Human Peripheral blood Mononuclear Cells. Frontiers in Immunology 9: 432.

Sundrum A, Butfering L, Henning M, Hoppenbrock K H. 2000. Effects of on-farm diets for organic pig production on performance and carcass quality. Journal of Animal Science 78(5): 1199-1205.

Wood J D, Richardson R I, Nute G R, Fisher A V, Campo M M, Kasapidou E, Sheard P R, Enser M. 2004. Effects of fatty acids on meat quality: A review. Meat Science 66(1):21-32.

Zhao J, Wang M, Xie J, Zhao M, Hou L, Liang J, Wang S, Cheng J. 2017. Volatile flavor constituents in the pork broth of black-pig. Food Chemistry 226:51-60. 


\section{Table $\mathbf{1}$ (on next page)}

Fatty acid (FA) composition( $\mathrm{g} / 100 \mathrm{~g}$ identified $\mathrm{FA}$ ) in L. lumborum of pork as affected by genetictype and lean grade.

Fatty acid (FA) composition(g/100 g identified FA) in L. lumborum of pork as affected by genetictype and lean grade. 
1 Table 1 Fatty acid (FA) composition (g/100 g identified FA) in L. lumborum of pork as affected by genetic type and 2 lean grade.

\begin{tabular}{|c|c|c|c|c|c|c|c|}
\hline & \multicolumn{2}{|c|}{ Genetic type } & \multicolumn{2}{|c|}{ Lean grade } & \multirow[t]{2}{*}{ SEM } & \multicolumn{2}{|l|}{ P-value ${ }^{\dagger}$} \\
\hline & $\begin{array}{l}\text { Pi x (L x } \\
\text { LW) }\end{array}$ & $\begin{array}{l}\text { Du x (Gc } \\
\times \mathrm{Du})\end{array}$ & $\begin{array}{l}<60 \% \\
\text { lean }\end{array}$ & $\begin{array}{l}>60 \% \\
\text { lean }\end{array}$ & & $\begin{array}{l}\text { Genetic } \\
\text { type }\end{array}$ & $\begin{array}{l}\text { Lean } \\
\text { grade }\end{array}$ \\
\hline N meat samples & 8 & 16 & 15 & 9 & & & \\
\hline Fat (IMF) & 2.05 & 2.26 & 2.23 & 2.08 & 0.03 & 0.63 & 0.75 \\
\hline \multicolumn{8}{|l|}{ Saturated FA (SFA) } \\
\hline C10:0, decanoic & 0.10 & 0.07 & 0.10 & 0.07 & 0.04 & 0.56 & 0.70 \\
\hline C12:0, dodecanoic & 0.11 & 0.10 & 0.12 & 0.08 & 0.01 & 0.64 & 0.05 \\
\hline C14:0, tetradecanoic & 1.39 & 1.52 & 1.50 & 1.41 & 0.05 & 0.10 & 0.29 \\
\hline C16:0, hexadecanoic & 21.91 & 22.97 & 22.55 & 22.33 & 0.39 & 0.08 & 0.73 \\
\hline $\mathrm{C} 17: 0^{1}$, heptadecanoic & 0.30 & 0.40 & 0.36 & 0.34 & 0.04 & 0.13 & 0.79 \\
\hline C18:0, octadecanoic & 11.96 & 11.77 & 12.24 & 11.48 & 0.29 & 0.67 & 0.12 \\
\hline C20:0, eicosanoic & 0.09 & 0.11 & 0.10 & 0.10 & 0.01 & 0.50 & 0.67 \\
\hline Sum of SFA & 35.86 & 36.93 & 36.97 & 35.81 & 0.42 & 0.10 & 0.10 \\
\hline \multicolumn{8}{|l|}{ Monounsaturated FA (MUFA) } \\
\hline C16:1, palmitoleic & 2.58 & 2.88 & 2.64 & 2.82 & 0.26 & 0.43 & 0.68 \\
\hline C17:1, heptadecenoic & 0.26 & 0.31 & 0.28 & 0.30 & 0.03 & 0.25 & 0.67 \\
\hline cis-9-18:12, cis-9-octadecenoic & 37.51 & 37.76 & 36.51 & 38.76 & 0.91 & 0.85 & 0.14 \\
\hline cis-11-18:1, cis-11-octadecenoic & 2.95 & 3.06 & 2.91 & 3.10 & 0.21 & 0.73 & 0.57 \\
\hline cis-11-20:12, cis-9-eicosenoic & 0.57 & 0.56 & 0.57 & 0.56 & 0.02 & 0.58 & 0.85 \\
\hline Sum of MUFA & 43.87 & 44.58 & 42.91 & 45.54 & 1.23 & 0.70 & 0.20 \\
\hline \multicolumn{8}{|l|}{ Polyunsaturated FA (PUFA) } \\
\hline C18:2 n-6, linoleic & 16.36 & 15.18 & 16.39 & 15.16 & 1.20 & 0.51 & 0.53 \\
\hline C18:3 n-6, $\gamma$-linolènic & 0.11 & 0.10 & 0.10 & 0.11 & 0.02 & 0.74 & 0.73 \\
\hline C18:3n-3, $\alpha$-linolenic & 1.28 & 1.19 & 1.31 & 1.16 & 0.12 & 0.62 & 0.43 \\
\hline C20:2, eicosadienoic & 0.58 & 0.46 & 0.53 & 0.48 & 0.04 & 0.13 & 0.44 \\
\hline C20:3 n-6, dihomo- $\gamma$-linolenic & 0.25 & 0.19 & 0.22 & 0.23 & 0.02 & 0.10 & 0.82 \\
\hline C20:3 n-3 eicosatrienoic & 0.15 & 0.14 & 0.18 & 0.11 & 0.02 & 0.55 & 0.05 \\
\hline $\mathrm{C} 20: 4 n-6$, arachidonic & 1.51 & 1.19 & 1.35 & 1.36 & 0.15 & 0.16 & 0.91 \\
\hline Sum of PUFA & 20.23 & 18.46 & 20.08 & 18.61 & 1.40 & 0.40 & 0.52 \\
\hline PUFA/SFA ratio & 0.57 & 0.50 & 0.55 & 0.52 & 0.04 & 0.31 & 0.70 \\
\hline MUFA/SFA ratio ${ }^{2}$ & 1.22 & 1.21 & 1.16 & 1.27 & 0.03 & 0.77 & 0.05 \\
\hline
\end{tabular}

$3{ }^{1}$ Pork from gilts showed greater C17:0 than that of barrows $(0.43 v s .0 .27 \pm 0.04 \%)$.

42 Pork from barrows showed greater cis-9-18:1, cis-11-20:1 and MUFA/SFA ratio than pork from gilts

$5 \quad$ (39.4 6 v. $35.82 \pm 1.04 \%$; 0.61 v. $0.52 \pm 0.02 \% ; 1.29$ v. $1.14 \pm 0.03 \%$, respectively).

$6 \uparrow$ Interaction genetic type $\mathrm{x}$ lean grade non-significant in any variable $(\mathrm{P}>0.05)$. 


\section{Table 2 (on next page)}

Effect of genetictype and lean grade on volatile compounds content; Hidrocarbons (expressed as $\mathrm{AU} \times 10^{4} / \mathrm{g}$ of cooked pork).

Effect of genetictype and lean grade on volatile compounds content; Hidrocarbons (expressed as $\mathrm{AU} \times 10^{4} / \mathrm{g}$ of cooked pork). 
1 Table 2 Effect of genetic type and lean grade on volatile compounds content; Hidrocarbons (expressed as AU x $10^{4} / \mathrm{g}$ 2 of cooked pork).

\begin{tabular}{|c|c|c|c|c|c|c|c|c|c|}
\hline \multirow[b]{2}{*}{ Volatile compounds } & \multirow[b]{2}{*}{ LRI } & \multirow[b]{2}{*}{$\mathrm{R}$} & \multicolumn{2}{|c|}{ Genetic type } & \multicolumn{2}{|c|}{ Lean grade } & \multirow[t]{2}{*}{ SEM } & \multicolumn{2}{|c|}{$P$-value } \\
\hline & & & $\begin{array}{l}\mathrm{Pix}(\mathrm{L} \\
\mathrm{x} \mathrm{LW})\end{array}$ & $\begin{array}{c}\mathrm{Dux} \\
(\mathrm{Gc} x \\
\mathrm{Du})\end{array}$ & $\begin{array}{c}<60 \% \\
\text { lean }\end{array}$ & $\begin{array}{c}>60 \% \\
\text { lean }\end{array}$ & & $\begin{array}{c}\text { Genetic } \\
\text { type }\end{array}$ & $\begin{array}{l}\text { Lean } \\
\text { grade }\end{array}$ \\
\hline \multicolumn{10}{|l|}{ Aliphatic hydrocarbons } \\
\hline Pentane & 517 & ms, lri,s & 81.87 & 109.60 & 96.22 & 95.24 & 36.70 & 0.62 & 0.99 \\
\hline n-Hexane & 563 & $\mathrm{~ms}$, lri & 75.92 & 60.85 & 64.97 & 71.80 & 23.03 & 0.66 & 0.84 \\
\hline Heptane & 677 & $\mathrm{~ms}$, lri & 25.82 & 34.41 & 37.16 & 23.07 & 14.19 & 0.69 & 0.51 \\
\hline 1-Octene & 818 & $\mathrm{~ms}$, lri & 26.06 & 29.14 & 33.24 & 21.96 & 12.80 & 0.87 & 0.56 \\
\hline Octane & 825 & ms, lri,s & 114.96 & 141.69 & 151.89 & 104.75 & 57.66 & 0.76 & 0.59 \\
\hline Nonane & 940 & $\mathrm{~ms}$, lri,s & 73.77 & 158.53 & 137.17 & 95.13 & 36.03 & 0.13 & 0.44 \\
\hline Hexane, 2,4,4-trimethyl- & 1074 & ms, lri & 78.86 & 74.10 & 21.90 & 131.06 & 27.66 & 0.91 & 0.02 \\
\hline Heptane, 3,3,4-trimethyl- & 1094 & $\mathrm{~ms}$, lri & 3.02 & 3.34 & 3.23 & 3.13 & 0.58 & 0.72 & 0.91 \\
\hline Undecane & 1119 & ms, lri,s & 59.35 & 59.84 & 56.39 & 62.80 & 8.56 & 0.97 & 0.62 \\
\hline Heptane, 4-methylene- & 1132 & $\mathrm{~ms}$, lri & 11.04 & 18.94 & 18.01 & 11.97 & 4.10 & 0.21 & 0.33 \\
\hline Dodecane & 1194 & $\mathrm{~ms}$, lri,s & 36.44 & 36.73 & 34.31 & 38.86 & 5.30 & 0.97 & 0.57 \\
\hline 1-Nonene & 1207 & $\mathrm{~ms}$, lri & 1.67 & 2.84 & 1.93 & 2.58 & 1.24 & 0.53 & 0.73 \\
\hline Tridecane & 1264 & ms, lri,s & 14.34 & 13.95 & 13.69 & 14.60 & 2.30 & 0.91 & 0.79 \\
\hline 1-Undecene, 9-methyl- & 1279 & $\mathrm{~ms}$, & 0.65 & 0.66 & 0.53 & 0.77 & 0.10 & 0.94 & 0.11 \\
\hline \multicolumn{10}{|c|}{ Aromatic and cyclic hydrocarbons } \\
\hline Toluene & 807 & ms, lri & 9.27 & 9.22 & 8.65 & 9.85 & 1.77 & 0.99 & 0.65 \\
\hline Cyclopropane, pentyl- & 819 & ms, lri & 6.26 & 33.25 & 21.94 & 17.56 & 13.40 & 0.19 & 0.83 \\
\hline Benzene, 1,3-dimethyl- & 930 & ms, lri & 5.56 & 5.00 & 3.97 & 6.59 & 1.74 & 0.83 & 0.33 \\
\hline $\begin{array}{l}\text { Phenol, 2,6-bis(1,1- } \\
\text { dimethylethyl)-4-(1- } \\
\text { methylpropyl)- }\end{array}$ & 1493 & $\mathrm{~ms}$, lri & 7.13 & 6.42 & 5.57 & 7.99 & 2.41 & 0.85 & 0.51 \\
\hline
\end{tabular}

3 LRI: Lineal Retention Index calculated for DB-624 capillary column $(30 \mathrm{~m} \times 0.25 \mathrm{~mm}$ id, $1.4 \mu \mathrm{m}$ film thickness $)$ 4 installed on a gas chromatograph equipped with a mass selective detector; R: Reliability of identification; lri: linear 5 retention index in agreement with literature (Gorbatov, 1980; Flores et al., 1997; Machiels et al., 2003; Domínguez et 6 al., 2014; Franco et al., 2014; Gravador et al., 2015; Benet et al., 2015; Zhao et al., 2017; Pérez-Santaescolástica et 7 al., 2018; Flores, 2018); ms: mass spectrum agreed with mass database (NIST14); s: mass spectrum and retention time 8 identical with an authentic standard.

$9 \dagger$ Interaction genetic type $\mathrm{x}$ lean grade non-significant in any variable $(\mathrm{P}>0.05)$. 


\section{Table 3 (on next page)}

Effect of genetictype and lean grade on volatile compounds content; Hidrocarbons (expressed as AU $\times 10^{4} / \mathrm{g}$ of cooked pork).

Effect of genetictype and lean grade on volatile compounds content; Hidrocarbons (expressed as $\mathrm{AU} \times 10^{4} / \mathrm{g}$ of cooked pork). 
1 Table 3 Effect of genetic type and lean grade on volatile compounds content: Aldehydes, Ketones and Carboxilic 2 acids (expressed as AU x 104/g dry matter) of cooked pork.

\begin{tabular}{|c|c|c|c|c|c|c|c|c|c|}
\hline \multirow[b]{2}{*}{ Volatile compounds } & \multirow[b]{2}{*}{ LRI } & \multirow[b]{2}{*}{$\mathrm{R}$} & \multicolumn{2}{|c|}{ Genetic type } & \multicolumn{2}{|c|}{ Lean grade } & \multirow[t]{2}{*}{ SEM } & \multicolumn{2}{|c|}{$P$-value ${ }^{\dagger}$} \\
\hline & & & $\begin{array}{l}\text { Pi x }(\mathrm{L} \mathrm{x} \\
\mathrm{LW})\end{array}$ & $\begin{array}{l}\mathrm{Du} \times(\mathrm{Gc} \\
\mathrm{x} \mathrm{Du})\end{array}$ & $\begin{array}{c}<60 \% \\
\text { lean }\end{array}$ & $\begin{array}{l}>60 \% \\
\text { lean }\end{array}$ & & $\begin{array}{l}\text { Genetic } \\
\text { type }\end{array}$ & $\begin{array}{l}\text { Lean } \\
\text { grade }\end{array}$ \\
\hline \multicolumn{10}{|l|}{ Aldehyde } \\
\hline Propanal & 527 & $\mathrm{~ms}$, lri,s & 68.09 & 68.13 & 71.52 & 64.70 & 14.76 & 1.00 & 0.76 \\
\hline Butanal, 3-methyl- & 661 & $\mathrm{~ms}$, lri & 6.68 & 18.93 & 17.97 & 7.64 & 11.79 & 0.49 & 0.56 \\
\hline Butanal, 2-methyl- & 673 & $\mathrm{~ms}$, lri & 4.08 & 12.54 & 10.65 & 5.97 & 5.23 & 0.29 & 0.55 \\
\hline Pentanal & 730 & ms, lri,s & 109.22 & 48.16 & 44.94 & 112.44 & 30.00 & 0.19 & 0.15 \\
\hline Hexanal & 869 & $\mathrm{~ms}$, lri,s & 1655.35 & 845.03 & 878.54 & 1621.8 & 454.74 & 0.25 & 0.29 \\
\hline Heptanal & 978 & $\mathrm{~ms}$, lri,s & 54.50 & 54.66 & 40.93 & 68.23 & 15.66 & 0.99 & 0.26 \\
\hline 2-Heptenal, (Z)- & 1042 & $\mathrm{~ms}$, lri & 4.39 & 5.42 & 4.79 & 5.01 & 0.66 & 0.31 & 0.82 \\
\hline Benzaldehyde & 1050 & $\mathrm{~ms}$, lri & 10.24 & 7.37 & 8.50 & 9.11 & 2.58 & 0.46 & 0.87 \\
\hline 2-Butenal, (Z)- & 1051 & $\mathrm{~ms}$, lri & 27.86 & 47.01 & 46.61 & 28.26 & 9.34 & 0.18 & 0.20 \\
\hline Octanal & 1071 & $\mathrm{~ms}$, lri,s & 13.35 & 14.87 & 11.18 & 17.04 & 4.22 & 0.81 & 0.36 \\
\hline 2-Octenal, (E)- & 1129 & ms, lri & 3.69 & 5.93 & 7.50 & 2.12 & 2.07 & 0.47 & 0.10 \\
\hline Nonanal & 1154 & $\mathrm{~ms}$, lri,s & 15.05 & 15.39 & 13.01 & 17.43 & 4.27 & 0.96 & 0.49 \\
\hline 2,4-Decadienal, (E,E)- & 1322 & $\mathrm{~ms}$, lri & 1.00 & 1.06 & 0.64 & 1.42 & 0.30 & 0.89 & 0.10 \\
\hline Ketone & & & & & & & 0,00 & & \\
\hline Acetone & 529 & $\mathrm{~ms}$, lri & 63.22 & 65.76 & 75.31 & 53.67 & 15.38 & 0.91 & 0.36 \\
\hline 2-Butanone & 595 & $\mathrm{~ms}$, lri & 5.78 & 8.79 & 11.44 & 3.13 & 2.76 & 0.47 & 0.06 \\
\hline 2-Pentanone & 722 & ms, lri & 5.39 & 4.09 & 6.30 & 3.18 & 1.48 & 0.56 & 0.17 \\
\hline 2,3-Pentanedione & 738 & ms, lri & 3.74 & 2.96 & 2.48 & 4.21 & 1.00 & 0.61 & 0.26 \\
\hline 3-Hydroxy-3-methyl-2- & 820 & ms, lri & 3.71 & 0.61 & 2.54 & 1.78 & 1.17 & 0.09 & 0.67 \\
\hline 1-Octen-3-one & 931 & $\mathrm{~ms}$, lri & 2.63 & 2.27 & 2.58 & 2.31 & 0.65 & 0.71 & 0.78 \\
\hline 2-Heptanone & 971 & $\mathrm{~ms}$, lri & 35.59 & 42.72 & 44.93 & 33.38 & 7.94 & 0.55 & 0.34 \\
\hline 2-Octanone & 1064 & $\mathrm{~ms}$, lri & 2.68 & 2.88 & 2.07 & 3.48 & 0.74 & 0.86 & 0.22 \\
\hline \multicolumn{10}{|l|}{ Carboxilic acid } \\
\hline Acetic acid & 697 & ms, lri & 3.66 & 5.38 & 4.77 & 4.26 & 1.91 & 0.55 & 0.86 \\
\hline Acetoin & 790 & $\mathrm{~ms}$, lri & 1106.92 & 859.55 & 1330.0 & 636.45 & 579.05 & 0.78 & 0.43 \\
\hline Butanoic acid & 923 & $\mathrm{~ms}$, lri & 2.17 & 1.67 & 1.37 & 2.48 & 0.45 & 0.46 & 0.11 \\
\hline Butanoic acid, 3-methyl- & 973 & $\mathrm{~ms}$, lri & 5.62 & 5.05 & 8.45 & 2.22 & 4.52 & 0.93 & 0.37 \\
\hline Pentanoic acid & 1089 & $\mathrm{~ms}$, lri & 9.62 & 8.55 & 7.62 & 10.54 & 2.65 & 0.79 & 0.47 \\
\hline $\begin{array}{l}\text { Pentanoic acid, 2-methyl-, } \\
\text { anhydride }\end{array}$ & 1142 & ms, lri & 13.64 & 15.36 & 14.22 & 14.77 & 2.99 & 0.70 & 0.90 \\
\hline Octanoic acid & 1230 & $\mathrm{~ms}$, lri & 1.11 & 0.40 & 0.71 & 0.80 & 0.31 & 0.13 & 0.85 \\
\hline
\end{tabular}

3 LRI: Lineal Retention Index calculated for DB-624 capillary column $(30 \mathrm{~m} \times 0.25 \mathrm{~mm}$ id, 
$4 \quad 1.4 \mu \mathrm{m}$ film thickness) installed on a gas chromatograph equipped with a mass selective detector; R: Reliability of 5 identification; lri: linear retention index in agreement with literature (Gorbatov, 1980; Flores et al., 1997; Machiels et 6 al., 2003; Domínguez et al., 2014; Franco et al., 2014; Gravador et al., 2015; Benet et al., 2015; Zhao et al., 2017; 7 Pérez-Santaescolástica et al., 2018; Flores, 2018); ms: mass spectrum agreed with mass database (NIST14); s: mass 8 spectrum and retention time identical with an authentic standard.

9 Interaction genetic type $\mathrm{x}$ lean grade non-significant in any variable $(\mathrm{P}>0.05)$. 


\section{Table 4(on next page)}

Effect of genetic type andl ean grade on volatile compounds content; Ester, Eter, Alcohol, Furan and Sulfur (expressed as AU x $10^{4} / \mathrm{g}$ dry matter) of cooked pork.

Effect of genetic type andl ean grade on volatile compounds content; Ester, Eter, Alcohol, Furan and Sulfur (expressed as AU x $10^{4} / \mathrm{g}$ dry matter) of cooked pork. 
1 Table 4 Effect of genetic type and lean grade on volatile compounds content: Ester, Eter, Alcohol, Furan and Sulfur 2 (expressed as AU x 104/g dry matter) of cooked pork.

\begin{tabular}{|c|c|c|c|c|c|c|c|c|c|}
\hline \multirow[b]{2}{*}{ Volatile compounds } & \multirow[b]{2}{*}{ LRI } & \multirow[b]{2}{*}{$\mathrm{R}$} & \multicolumn{2}{|c|}{ Genetic type } & \multicolumn{2}{|c|}{ Lean grade } & \multirow[t]{2}{*}{ SEM } & \multicolumn{2}{|c|}{$P$-value ${ }^{\dagger}$} \\
\hline & & & Pi x (L & Du $x$ & $<60 \%$ le & $>60 \%$ & & Geneti & Lean \\
\hline \multicolumn{10}{|l|}{ Ester and ether } \\
\hline Acetic acid ethenyl ester & 589 & $\mathrm{~ms}$, lri & 61.40 & 26.30 & 63.16 & 24.53 & 23.52 & 0.35 & 0.26 \\
\hline Ethyl Acetate & 600 & $\mathrm{~ms}$, lri & 63.17 & 40.79 & 89.29 & 14.67 & 60.85 & 0.81 & 0.42 \\
\hline Acetic acid, butyl ester & 1069 & $\mathrm{~ms}$, lri & 13.12 & 13.86 & 9.35 & 17.63 & 3.88 & 0.90 & 0.17 \\
\hline Alcohol & & & & & & & 0,00 & & \\
\hline 1-Propanol, 2-methyl- & 649 & $\mathrm{~ms}$, lri & 11.40 & 31.52 & 17.28 & 25.64 & 12.84 & 0.31 & 0.67 \\
\hline 1-Butanol & 709 & ms, lri & 3.51 & 6.10 & 6.49 & 3.12 & 0.875 & 0.06 & 0.02 \\
\hline 3-Buten-1-ol, 3-methyl- & 805 & $\mathrm{~ms}$, lri & 12.20 & 23.18 & 19.89 & 15.49 & 8.98 & 0.42 & 0.75 \\
\hline 1-Butanol, 3-methyl- & 811 & ms, lri & 138.99 & 239.02 & 215.79 & 162.22 & 81.29 & 0.42 & 0.66 \\
\hline 1-Pentanol & 850 & ms, lri & 237.22 & 356.03 & 356.48 & 236.77 & 31.46 & 0.02 & 0.02 \\
\hline 2,3-Butanediol & 913 & $\mathrm{~ms}$, lri & 61.86 & 24.44 & 57.87 & 28.43 & 19.28 & 0.20 & 0.28 \\
\hline 2,3-Butanediol, [S-(R*, R*)]- & 921 & ms, lri & 19.05 & 18.20 & 23.89 & 13.36 & 7.98 & 0.94 & 0.34 \\
\hline 1-Hexanol & 959 & ms, lri & 891.06 & 1886.34 & 1645.30 & 1132.10 & 413.83 & 0.12 & 0.42 \\
\hline 1-Heptanol & 1050 & $\mathrm{~ms}$, lri & 44.24 & 42.54 & 44.19 & 42.60 & 13.38 & 0.93 & 0.94 \\
\hline 1-Octen-3-ol & 1056 & ms, lri & 347.75 & 450.68 & 420.37 & 378.07 & 54.80 & 0.22 & 0.61 \\
\hline 2-Ethyl-1-hexanol & 1099 & $\mathrm{~ms}$, lri & 3.70 & 3.97 & 3.79 & 3.87 & 0.63 & 0.77 & 0.93 \\
\hline 1-Octanol & 1132 & $\mathrm{~ms}$, lri & 13.62 & 21.11 & 19.66 & 15.07 & 4.37 & 0.26 & 0.49 \\
\hline Phenylethyl Alcohol & 1189 & ms, lri & 6.03 & 9.34 & 10.72 & 4.66 & 2.93 & 0.46 & 0.18 \\
\hline 1-Nonanol & 1207 & $\mathrm{~ms}$, lri & 4.16 & 5.83 & 3.19 & 6.79 & 2.66 & 0.68 & 0.37 \\
\hline 1-Tetradecanol & 1472 & ms, lri & 4.04 & 4.42 & 4.76 & 3.70 & 1.68 & 0.88 & 0.67 \\
\hline \multicolumn{10}{|l|}{ Furans } \\
\hline Furan, 2-ethyl- & 706 & ms, lri & 6.67 & 10.73 & 8.77 & 8.63 & 2.09 & 0.21 & 0.97 \\
\hline 2-n-Butyl furan & 948 & $\mathrm{~ms}$, lri & 4.01 & 4.54 & 4.24 & 4.31 & 0.95 & 0.71 & 0.96 \\
\hline Furan, 2-pentyl- & 1043 & $\mathrm{~ms}$, lri & 79.08 & 103.76 & 94.44 & 88.41 & 21.71 & 0.45 & 0.85 \\
\hline \multicolumn{10}{|l|}{ Sulphur compounds } \\
\hline Methanethiol & 505 & ms, lri & 3.07 & 1.43 & 3.41 & 1.09 & 1.54 & 0.48 & 0.32 \\
\hline Carbon disulfide & 535 & $\mathrm{~ms}$, lri & 11.24 & 9.95 & 10.93 & 10.26 & 1.76 & 0.63 & 0.80 \\
\hline
\end{tabular}

LRI: Lineal Retention Index calculated for DB-624 capillary column $(30 \mathrm{~m} \times 0.25 \mathrm{~mm}$ id, $1.4 \mu \mathrm{m}$ film thickness $)$ installed on a gas chromatograph equipped with a mass selective detector; R: Reliability of identification; lri: linear retention index in agreement with literature (Gorbatov, 1980; Flores et al., 1997; Machiels et al., 2003; Domínguez et al., 2014; Franco et al., 2014; Gravador et al., 2015; Benet et al., 2015; Zhao et al., 2017; Pérez-Santaescolástica et al., 2018; Flores, 2018); ms: mass spectrum agreed with mass database (NIST14); s: mass spectrum and retention time identical with an authentic standard.

$\dagger$ Interaction genetic type $\mathrm{x}$ lean grade non-significant in any variable $(\mathrm{P}>0.05)$. 


\section{Figure 1}

Figure 1 Volatile compounds (AU x 104/total volatile compound AU x 104) recorded in organic pork quantified and grouped according to their chemical families (a) and their origin (b)

Figure 1 Volatile compounds (AU x 104/total volatile compound AU x 104) recorded in organic pork quantified and grouped according to their chemical families (a) and their origin (b) to Dainty et al. (1985), Roger, Degas and Gripon (1988), Ruiz et al. (1999), Meynier et al.(1999), Carrapiso et al. (2002), Arnoldi (2003), Liu (2003), Machiels et al. (2003), Raes et al. (2003), Martín et al. (2006), Ramírez and Cava (2007), Calkins and Hodgen (2007), Narváez-Rivas et al. (2012), Fonseca et al. (2015) and Rivas, Gallardo and Camacho (2016). 


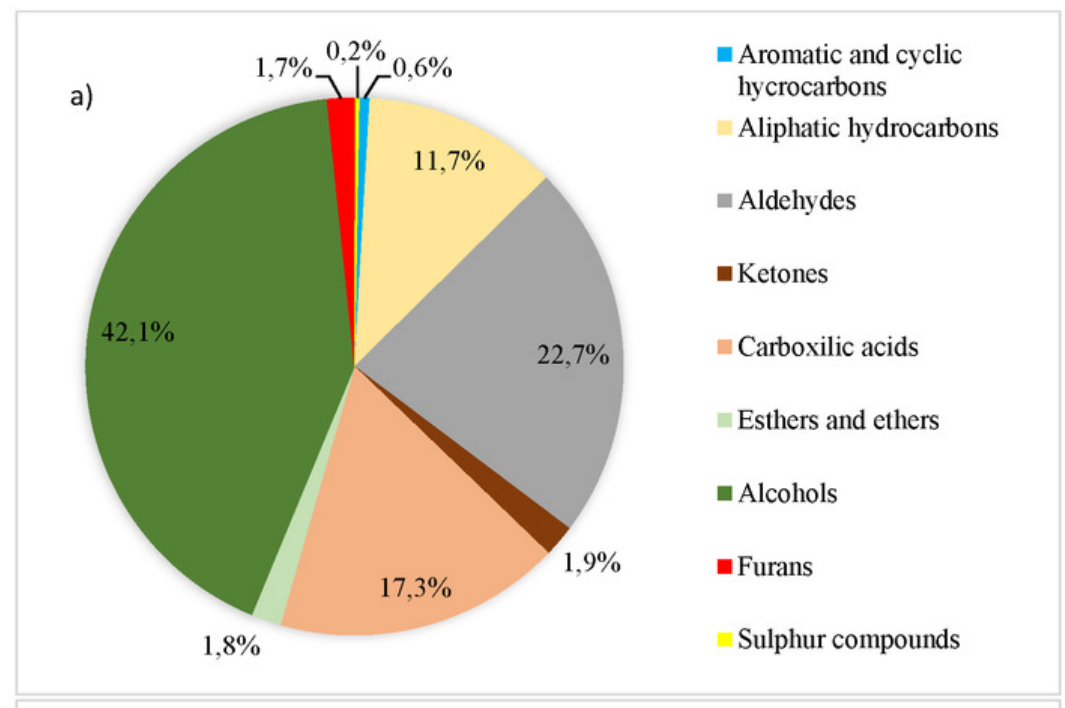

b)

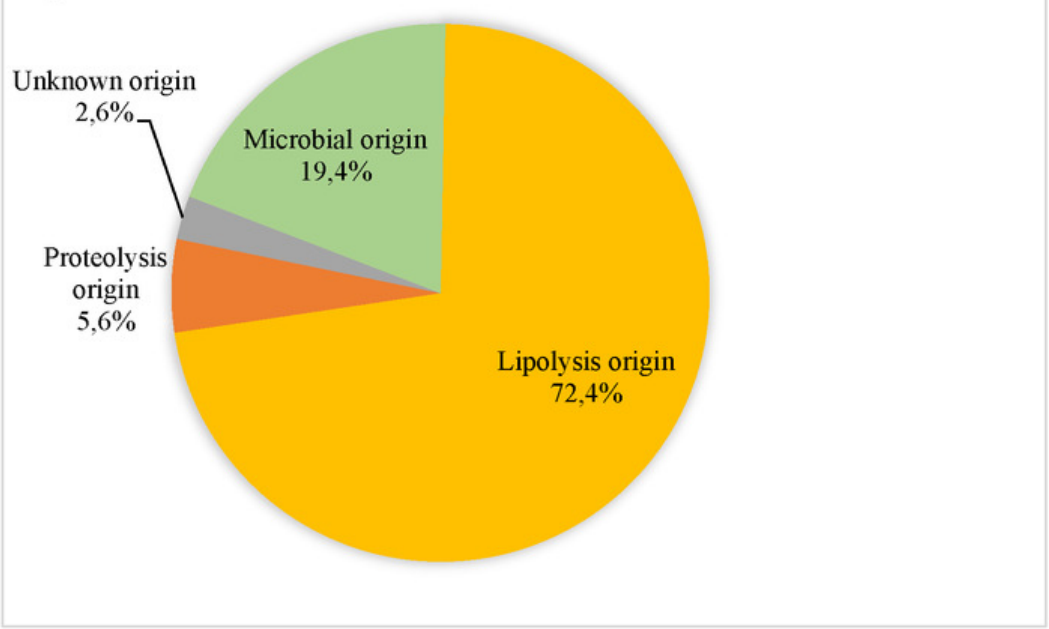


Figure 2

Partition tree of fatty acids (a) and volatile compounds (b) of organic pork based on genetic type, showing the two splits and the proportion of observations in each split.

Partition tree of fatty acids (a) and volatile compounds (b) of organic pork based on genetic type, showing the two splits and the proportion of observations in each split.
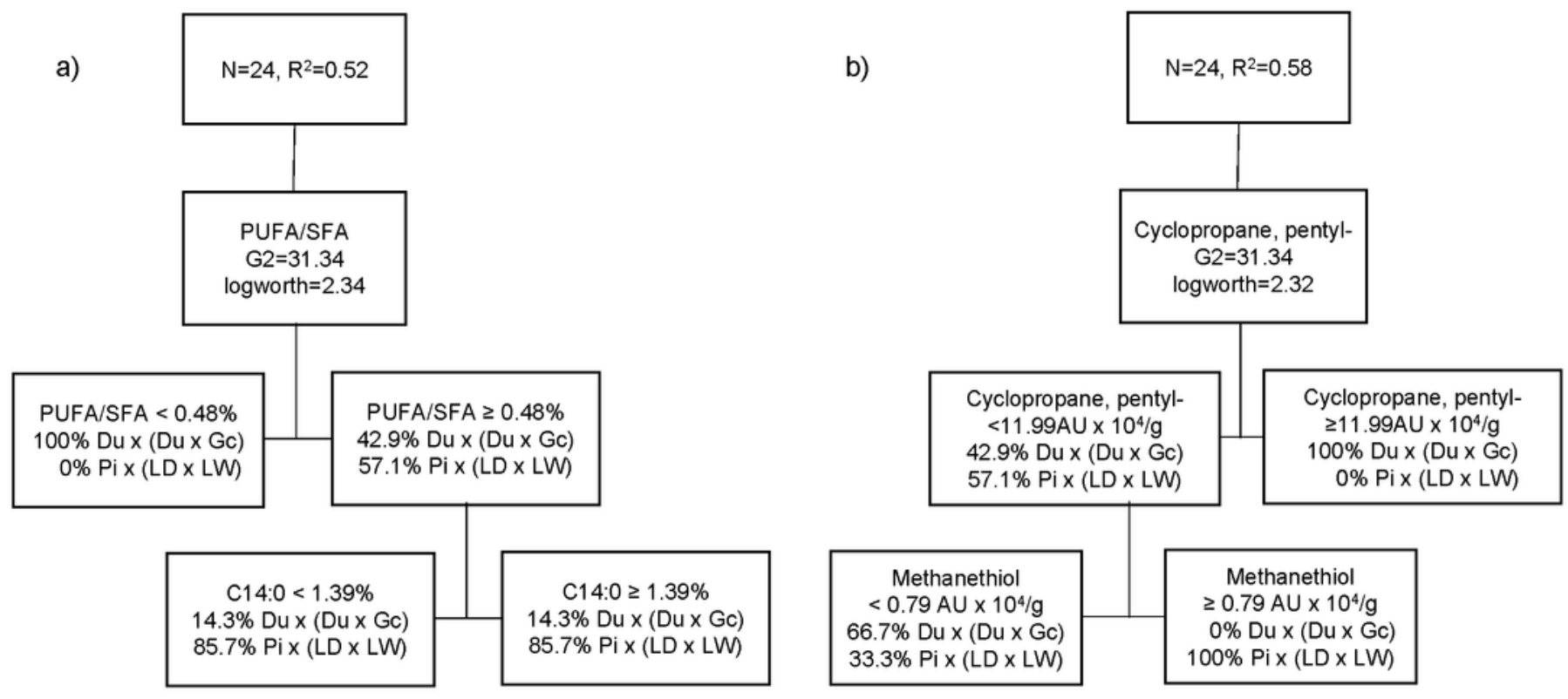
Figure 3

Partition tree of fatty acids (a) and volatilecompounds (b) of organic pork based on lean grade, showing the two splits andthe proportion of observations in each split.

Partition tree of fatty acids (a) and volatilecompounds (b) of organic pork based on lean grade, showing the two splits andthe proportion of observations in each split.

a)

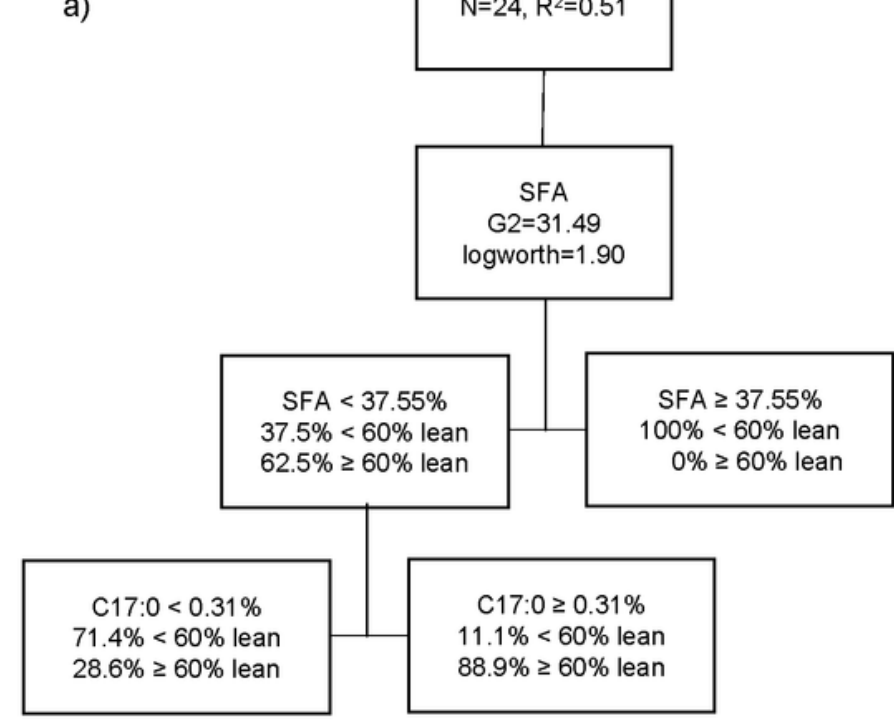

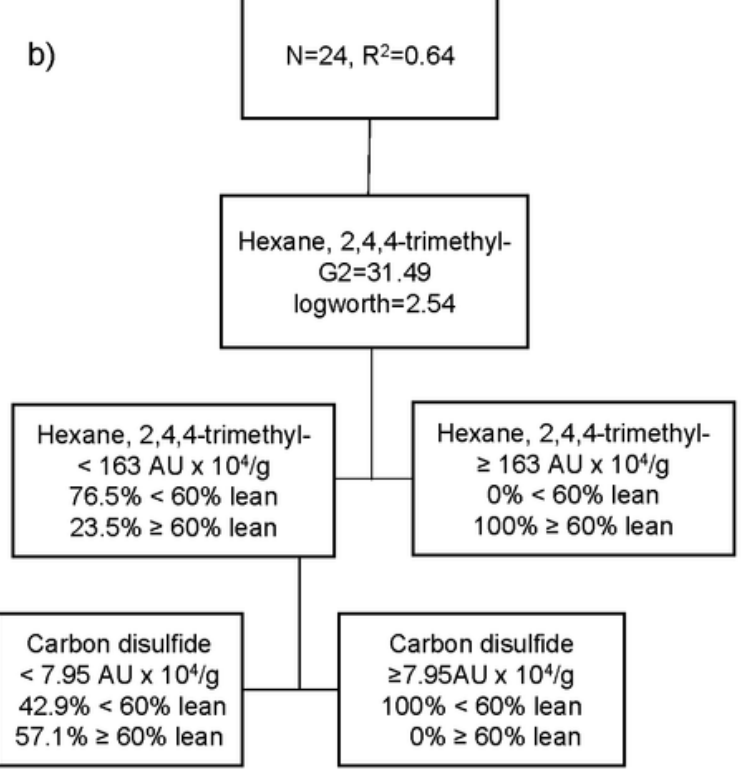

